\title{
ERP Critical Success Factors: Software system Engineering Perspective
}

\author{
Nafisa Osman \\ Sudan University of Science and Technology \\ Khartoum, Sudan
}

\author{
Abd-El-kader Sahraoui \\ LAAS-CNRS, Université de Toulouse \\ 31400 Toulouse, France
}

\begin{abstract}
Past research has identified critical success factors to the successful implementation of ERP system. This paper reviews critical success factors of ERP which defined through application of literature review on critical success factors (CSFs) approach and CSFs of requirement engineering. ithas been analyzed CSFs from requirement engineering perspective; the findings show that CSFs of ERP are associated to requirement engineering activities
\end{abstract}

\section{Keywords}

ERP; software engineering; requirements engineering; project management

\section{INTRODUCTION}

The concept of critical success factors (CSFs) was first introduced in Harvard business review article entitled "chief executives define their own data needs" by Rockart. The words "critical success factors" are beginning take their place with other basic terms concerned with the management of an organization. Like goals and objectives, CSFs appears at various levels in the management hierarchy.[1]

CSFs are the limited numbers of areas in which satisfactory results will ensure successful competitive performance for the individual, department or organization. CSFs are the few key areas where "things must go right" for the business to flourish and for the manager's goals to be attained. [1]

Many studies defines CSFs for ERP implementation phase and post implementation phase in general check [2]-[4] or based on different criteria such as country check [5]-[7] and many others .[8] Study CSFs of ERP from stakeholder perspective. This paper discusses CSFs of ERP from software engineering perspective (requirement engineering phase).

\section{CRITICAL SUCCESS FACTOR FOR REQUIREMENT ENGINEERING}

Requirement engineering is the first activity of software engineering and its critical stage as errors at RE inventible lead to later problems in the system design and implementation. [9]identifying the related critical success factors is most important to ensuring right requirement to be determined in order to improve RE process and software development process[10]. Table [1] summarizes CSF for requirement engineering activity.

Table 1. Critical success factors of RE

\begin{tabular}{|c|}
\hline Success factor \\
\hline Stakeholder involvement \\
\hline Experienced staff \\
\hline Clear scope and relevant goal \\
\hline
\end{tabular}

\begin{tabular}{|c|}
\hline Customer expectation management \\
\hline Simplicity of RE process \\
\hline Sharing of best practices \\
\hline Roles and responsibility \\
\hline Using different forms / models to represent requirements \\
\hline Training and education \\
\hline Automated tools \\
\hline
\end{tabular}

\subsection{Critical Success Factors for ERP Implementation}

Table [2] summarize the critical success factors of ERP after careful analysis of CSFs mentioned at the previous studies.

Table 2.critical success factor of ERP implementation.

\begin{tabular}{|c|c|}
\hline \# & CSF \\
\hline 1. & Good project scope management \\
\hline 2. & Management expectations \\
\hline 3. & Project management \\
\hline 4. & Steering committee \\
\hline 5. & Legacy system \\
\hline 6. & Culture change / political issue and regulation \\
\hline 7. & Formalized project /plan schedule \\
\hline 8. & Business process reengineering \\
\hline 9. & Experience project manager leadership \\
\hline 10. & Project champion role \\
\hline 11. & Trust between partners \\
\hline 12. & Interdepartmental cooperation and communication \\
\hline 13. & $\begin{array}{l}\text { Project team composition /team skill and team } \\
\text { competence }\end{array}$ \\
\hline 14. & Empowered decision maker \\
\hline 15. & $\begin{array}{l}\text { Management involvement. Support and } \\
\text { commitment }\end{array}$ \\
\hline 16. & $\begin{array}{lll}\text { Monitor and } & \begin{array}{l}\text { evaluation } \\
\text { and performance }\end{array} & \text { progress }\end{array}$ \\
\hline 17. & Appropriate use and managing consultant \\
\hline 18. & Vendor tools \\
\hline
\end{tabular}




\begin{tabular}{|c|c|}
\hline 19. & $\begin{array}{c}\text { Appropriate technology and good } \\
\text { infrastructure }\end{array}$ \\
\hline 20. & Reduce trouble shooting and project risk \\
\hline 21. & Training software \\
\hline 22. & Education on new business process \\
\hline 23. & Vendor support \\
\hline 24. & Data analysis and conversation \\
\hline 25. & Formal ERP implementation methodology \\
\hline 26. & $\begin{array}{cc}\text { Careful define information and system } \\
\text { requirements }\end{array}$ \\
\hline 27. & Adequate ERP software selection \\
\hline 28. & Clear goal and objectives \\
\hline 29. & Careful change management \\
\hline 30. & End user involvement \\
\hline 31. & Organization fit ERP \\
\hline 32. & Motivational factor for ERP implementation \\
\hline 33. & Company wide support \\
\hline 34. & Business plan long term vision \\
\hline 35. & Vendor/customer partnership \\
\hline 36. & Integration business plan with ERP planning \\
\hline 37. & Ease of system use and user acceptance \\
\hline 38. & Data and information quality \\
\hline 39. & Focus on user requirement \\
\hline 40. & Rewards and recognition \\
\hline 41. & Standardized implementation sequence \\
\hline 42. & End user satisfaction \\
\hline 43. & Software reliability \\
\hline 44. & Adequate testing of system \\
\hline
\end{tabular}

For proper CSFs discussion and prevent repeating, it has been categorized into eight groups, described below in table [3]

Table 3. ERP CSFs categorization

\begin{tabular}{|c|c|}
\hline \multirow{4}{*}{$\begin{array}{c}\text { Group name } \\
\text { project management and } \\
\text { planning }\end{array}$} & CSF \\
\cline { 2 - 2 } & $\begin{array}{c}\text { Formalized project plan and } \\
\text { schedule }\end{array}$ \\
\cline { 2 - 2 } & $\begin{array}{c}\text { Pusiness plan long term } \\
\text { vision }\end{array}$ \\
\cline { 2 - 2 } & Clear goal and objectives \\
\cline { 2 - 2 } & Monitor and evaluate project \\
\hline \multirow{4}{*}{$\begin{array}{c}\text { Experience project manager } \\
\text { leadership }\end{array}$} \\
\cline { 2 - 2 } & Project champion role \\
\hline
\end{tabular}

\begin{tabular}{|c|c|}
\hline \multirow[t]{4}{*}{ team management } & $\begin{array}{l}\text { Project team composition } \\
\text { /team skill and team } \\
\text { competence }\end{array}$ \\
\hline & Vendor/customer partnership \\
\hline & Vendor support \\
\hline & $\begin{array}{l}\text { Appropriate use and } \\
\text { managing consultant }\end{array}$ \\
\hline \multirow{3}{*}{ Top management } & Steering committee \\
\hline & $\begin{array}{l}\text { Management involvement. } \\
\text { Support and commitment }\end{array}$ \\
\hline & Empowered decision maker \\
\hline \multirow{3}{*}{ Training and education } & Training software \\
\hline & Education on new business \\
\hline & $\begin{array}{c}\text { Ease of system and user } \\
\text { acceptance }\end{array}$ \\
\hline \multirow{2}{*}{$\begin{array}{l}\text { ERP selection and fit } \\
\text { organization }\end{array}$} & Organization fit ERP \\
\hline & $\begin{array}{l}\text { Adequate ERP software } \\
\text { selection }\end{array}$ \\
\hline \multirow[t]{2}{*}{ implementation methodology } & $\begin{array}{l}\text { Formal implementation } \\
\text { methodology }\end{array}$ \\
\hline & $\begin{array}{c}\text { Standardized implementation } \\
\text { sequence }\end{array}$ \\
\hline \multirow[t]{3}{*}{ data migration } & Data and information quality \\
\hline & $\begin{array}{l}\text { Data analysis and } \\
\text { conversation }\end{array}$ \\
\hline & Software reliability \\
\hline \multirow[t]{2}{*}{ Requirement } & $\begin{array}{l}\text { Careful define information } \\
\text { and system requirement }\end{array}$ \\
\hline & Focus on user requirement \\
\hline
\end{tabular}

Other CSFs discussed as mentioned on table above.

\subsection{Discussion of ERP CSFs}

\subsubsection{Good project management:}

Good project management is essential in an ERP implementation project. The project management activities span the first four stages of the ERP life cycle from beginning the project until closing it. because ERP projects tend to be huge and inherently complex, due to the extensive combination of hardware and software as well as the countless organizational, human and political issues.[11], [12]

Planning a sophisticated ERP project should not be taken lightly or with little forethought. As mentioned before, there are enormous potential costs associated with such an undertaking. In addition to the high costs paid out before the go-live date, there can and have been major expenses incurred by companies that were unable to fully develop a comprehensive plan. Planning should be closely identified with maintaining scope during an implementation. This plan should state strategic and tangible benefits, resources, costs, risks, and timeline.[13]

A crucial part of working with the ERP functionality is the ability to streamline operations. When implementing a system, many organizations fail to specify their organizational 
objectives. Companies that do not understand these issues early on will face serious problems.[14]

Scope is the initial "blueprint" of an implementation plan. Within this original plan, budgetary and resource needs are established. During the course of the project, it can be easy, often transparently so, to become so involved in details that additional responsibilities or requirements are added or affected. Suddenly, but often too late, the realization comes that the project is a victim of "scope creep". The ability to maintain scope is closely related to planning, and it is possible to achieve for companies both large and small[13]

\subsubsection{Project team: consultant, leadership and champion}

The ERP team should consist of the best people in the organization. Building a cross-functional team is also critical[15]. The project team must contain a mix of internal and external staffs so that internal staffs can develop technical skills for design, implementation and later usage. The internal staffs should be a mix of technical, business experts and end-users from different business units in company. Moreover, they should be balanced and key staffs in the company. Further, the project team should be empowered in decision making for continuous implementation progress. External staffs should contain wellknown ERP implementers, vendors and consultants.[16]

Besides, the project team must be dedicated to work full time on the project. Therefore, they need to be supported, encouraged, and rewarded to maintain high enthusiasm during implementation.[13]

The ERP consultant or advisory firm should be involved as soon as company realizes its needs for ERP project. The role of ERP consultants is to consult company in defining new business process and choosing the suitable ERP package. Therefore, the consultant should have multiple skills covering functional, technical issues and in-depth knowledge of the software[17] [19]

Additionally, project manager appointed should be experienced, mix of business and IT knowledge, strong leadership skills and have adequate authority to manage all aspects of the project. Besides, the project manager must be mix of technical, business and change management requirements. It is also important that he must understand the company's business process. A competent project manager has crucial role in ERP implementations The attitude of senior managers will affect not only the flow of funds and information to the project, but also the subordinates view the project, its future impact upon the company as a whole, and its impact upon the employees as valued and capable individuals.[18], [20], [21]

\subsubsection{Top management}

This concept is referred to the need of having committed leadership at the top management level, Successful ERP implementation very much depends upon active and persistent top management involvement, and the importance of top management support in each step in all company levels is crucial[20]. Top management support and commitment is needed throughout the ERP adoption process because the project must receive approval and align with strategic business goals[16], [17]. Top managers must commit themselves to involve in the project for allocating the required personnel resource for implementation and giving appropriate time to finish the job. A share vision of the company and the role of the new system and structures should be communicated between managers and employees. Moreover, top managers should be the persons to harmonize any conflicts between internal and external parties. [22]

Top management should not entrust their duties of ERP implementation to their technological departments because it is more than a technological challenge. Project planning, forming the project team, choosing the ERP package and the ERP implementer, the project sponsor and supervisor are among the duties that can only be done by top managers.[23]

Conclude that not only should the top management be active in the implementation process, but to ensure progress and ultimately success. They should also be able to anticipate glitches that might occur; this naturally puts a great demand on their knowledge regarding ERP systems and the implementation process strategic planning and leadership but also of technical expertise. This knowledge can express itself in understanding the importance of delegating enough resources to the project in order for it to be successful.[20]

\subsubsection{Training and education}

The aim of education and training for end-users is to help them they gradually get used to new working habits behind the new system. In other words, they should be educated new business processes and know how to use the system properly. Hence, there should have an appropriate plan for training facilities and budget to ensure effective and continuous training for existing end-users and newcomers. Internal IT department and external staffs should play the main role in education and training. Education and training should be a carried out seriously and endusers are supported during training program. Further, management needs to consider how to allocate end-users after the ERP implementation stage[19], [24]

Some difficulties in users training are the diversity of the users (IT skills, age), the complexity of the new systems (interfaces, functions) and different available training methods (web-based virtual training, computer-based training, and video courses).[24]

Lack of user training and misunderstanding the enterprise applications appear to be two large reasons responsible for many ERP implementation failures. ERP implementations require a vast amount of knowledge to enable people to solve problems that may occur within the framework of the system.[11] to make system user training successful, the training should preferably start well before the implementation process begins[25]

In order to build user acceptance with regards to the project and nurture a positive employee attitude, training and education can be used as a tool to achieve those goals.

\subsubsection{Change management}

Change management is a method or procedure to manage the transition from using old systems to adopting new ones effectively. In ERP adoption, this factor refers the need for a company and its employees ready for changes. Specifically, a company should formally prepare as soon as possible a change management program to deal with the complex organizational problems of employees"e resistance, confusion and redundancies, and errors regarding to the new system. Top managers can inform employees about the new project in early stages or build user acceptance through education about the benefits and need for an ERP system in order to get positive attitudes towards it

Change management is important, starting at the project phase and continuing throughout the entire life cycle. Enterprise wide culture and structure change should be managed which include people; organization and culture change.[26] Not unexpectedly, the most common failure factor reported was that of "readiness 
for change". Implementing an ERP system completely changes the culture within an organization, and many companies have found themselves hard pressed to accomplish this successfully. [13]

Change program should cover end user involvement and training in the implementation stage and they must be regularly supported from top management or implementation team. The project planning must be looked upon as a change management initiative not an IT initiative.[17], [21], [22], [27]

\subsubsection{Business process re-engineering}

A process is "a lateral or horizontal organizational form that encapsulates the interdependence of tasks, roles, people, departments and functions required to provide a customer with a product or service". A business process is "comprised of the people who conduct it, the tools they use to assist them, the procedures they follow and the flows of material and information between the various people, groups and subactivities". Business process includes operational and infrastructure process. Operational process refers to business functions such as product development, order management, and customer support whereas infrastructure process is more administrative including establishing and implementing strategy and managing human resources or physical assets

Business process re-engineering, BPR is "the fundamental rethinking and radical redesign of business processes to achieve dramatic improvements in critical, contemporary measures of performance, such as cost, quality, service and speed". The importance of BPR is to create the best way of doing business, so it changes the way of working of a company. the most important outcome of BPR has been viewing business activities as more than a collection of individual or even functional tasks; it has engendered the process-oriented view of business. To be clear, the company's business strategy indicates what it wants to do, BPR indicates how to do it and the ERP system answers the question with what. There are several modeling techniques used in BPR process: data flow-oriented methods (dataflow diagrams, flowcharts), object-oriented methods (use case diagram, state chart diagram, and activity diagram) and control flow-oriented methods

ERP systems provide best practices in doing business for industry domains, not for a specific company. Therefore, many companies consider customizing the ERP software to fit its business characteristics or even to its business processes.

In literature, BPR and minimal customization is the third most commonly cited CSF. In order to obtain full benefits of ERP implementation, it is advised to reengineer the existing business processes to best practices integrated on the system. Firstly, the ERP system itself cannot improve the company's performance without reengineering the current business process. Another reason is that modification of the software will cause some problems including software license cost, code errors, maintenance and difficulty in upgrading to newer versions and releases. Once the ERP system is in use, BPR should be continued with new ideas and updates to get full benefits of the system. All in all, company should be willing to change its business processes to fit the software in order to minimize the degree of customization needed.

\subsubsection{User involvement}

It is definitely essential for the success of ERP adoption. Endusers should be involved in early stage of design and implementation to improve user requirements and understand the new system as well as give feedback from their own point of views to enhance system quality. Since the end-users understand the ideas of new system sooner, they will have positive attitude; their resistance to the new system will be reduced; and training is more easily accepted. Moreover, end-users involvement is helpful in the ERP configuration analysis and in data conversion as well as in system testing.[18], [24]

The users are in many cases, often afraid that the ERP implementation will change their role, job status, importance, responsibilities and the access of valuable information [4]. The user involvement can hence, be referred to a psychological state of the individual as the importance and personal relevance of the system to the user [28]. Beyond the CSF as mentioned above; i.e. education and training, it is important to get users involved during the development of the system, get a hold of the existing knowledge from the user in areas where the team have insufficient expertise[18]. emphasize the activity of nominate user delegates that contain solid knowledge of the organizational processes, thus, be in charge of the cross-functional requirements in the redesigns of the processes, activities and functional areas both during the initial implementation and over time. Therefore, the user involvement and participation are considered critical success factors as they will result in a better fit of user requirements and enhancing a better system quality, use and acceptance

\subsubsection{Adequate testing}

System testing has proven to be the key element of success for some companies and a direct cause of failure for others. after months or years of development, it may be feasible to assume that both team members as well as executive management are tired of dealing with the project and just want it to be completed. The result of this myopic thinking, however, is that testing is reduced or ignored, and "red flags" are disregarded."[13]

The organization implementing ERP should work well with vendors and consultants to resolve software problems. Quick response, patience, perseverance and problem solving capabilities are important [26]. Vigorous and sophisticated software testing eases implementation

\subsubsection{Reduce trouble shooting and project risk}

risk management which involves developing proper troubleshooting tools, adequate skills and techniques and in relation to the CSF use of consultants, working closely with vendors and consultants when something is wrong in the system [4]. Troubleshooting errors is critical when implementing an ERP, and the relationship with vendors and consultants to resolve software problems should also work well [22], [27]

the nature of ERP project risk is determined by the risk factors; hence they suggest a risk management approach to mitigate the risks of ruining the project. Stated different phases in descending order; context analysis, risk identification, risk analysis, risk evaluation, risk treatment, monitoring and review and lastly communicating and consulting[29]. Thus, managers can consider measuring the risk within an ERP project as an important part of risk management[30]. However, despite having a proper risk management strategy, the users should be the one having the knowledge about any contingency plan if the errors occur, thus, the know-how of troubleshooting the system when the system is live. If they do not have the knowledge of doing that, they might get over-reliant on the vendor to resolve technical queries [31]

\subsubsection{Selecting ERP}

The fit between the company and the ERP system of choice is paramount to the success of the process. Choosing an ERP system which does not fit the organizational processes to a certain extent will lead to the company struggling to adapt, spending precious resources and ultimately having to abandon 
the conversion as a whole and try again[32]. As the process is very costly and time-consuming, companies should not take this matter lightly. Selecting the right system also means selecting the right vendor to distribute the system.

Selecting the right ERP system from the start is vital to the success of the implementation process. For a company to be able to choose the right ERP system, the implementation phases need to be carefully worked through [33]. the ERP system must match the business processes of the company for it to be successfully implemented.

\subsubsection{ERP implementation methodology}

Several questions have to be asked in order to form a wellfunctioning strategy for implementation; what are the specific information needs at operational and managerial levels, how will the ERP system integrate with the existing system, and what is the schedule for the implementation? Answering these questions, the company can develop a plan which would increase their chances of success with $90 \%$ compared to companies without a plan [34]. Many researchers promote a phased approach to the implementation since it gives the company flexibility to make changes in the timeframe should any unforeseeable events occur [34]-[36]

\subsubsection{Communication}

Failing to achieve a fluent and open communication between top management and the system user is a major cause of ERP implementation failure [37]. a company encouraging its employees to participate actively in the implementation is more successful than a company that does not. the importance of open communication when sharing the news of the change of ERP systems as well as the ongoing updates regarding the change. Indeed, cross functional and interdepartmental coordination is of utmost importance when implementing an ERP system and having excellent company-wide communication is vital [30]. communication is an important tool to use for management when trying to avoid resistance to change from their employees. Continuous communication with the whole company will let the system users know what is happening, what results are to be expected and if something goes awry, they are directly informed and involved in solving the problem instead of left behind in confusion [38].

\subsubsection{Data analysis and conversation}

The success of the implementation process and ultimately of the total success of the system relies on the ability of the team to ensure data accuracy when converting it into the new system [11], [12], [25]

the conversion process of the implementation may involve cleaning up suspect data that is not required in the new ERP system[19]. The conversion process should be such that there is a minor chance of loss of data during the migration [36]. This part of the implementation also involves ensuring the system reliability, system integrity, stability and compatibility of the software

\subsubsection{Appropriate technology and good IT infrastructure}

The issue of IT infrastructure is one of the reasons for high failure rate of ERP adoption. Therefore, it is critical to evaluate company's current IT readiness, including architecture and skills, before implementation. Since ERP implementation involves a complex transition from legacy systems and business processes to an integrated infrastructure and common business process throughout a company, it is necessary to upgrade or revamp the poorly current IT infrastructure.[11], [12], [19]

\subsubsection{Legacy system}

There must also be consideration of the current legacy system in place as this will be a good indicator of the nature and scale of potential problems. This could directly affect the technical and organizational change required

\subsubsection{Cultural change}

Davison (2002) suggests that there is a critical need to be consciously aware of the cultural differences and preferences from both organizational and geographical perspectives. Therefore, it is necessary to understand the business characteristics [39] and the need for a culture that is conducive to change[22]. Adoption costs from the perspectives of all stakeholders must be reduced as much as possible [40]. Finally, consideration must be given to the identification and usage of strategies that are necessary to implement cultural change.

\section{REQUIREMENT ENGINEERING VIEW for CSF}

After reviewing CSFS for ERP and RE activities taking into consideration ERP phase is attempt to embed organization needs in ERP packages. The research defined most CSFs for ERP has an interrelationship with RE activities. table [3] summarize them.

Table 3. CSF for ERP related to RE

\begin{tabular}{|l|l|}
\hline \multicolumn{1}{|c|}{$\#$} & CSF \\
\hline 1. & Good project scope management \\
\hline 2. & Culture change / political issues and regulation \\
\hline 3. & Management involvement, support and commitment \\
\hline 4. & Careful define information and system requirement \\
\hline 5. & Clear goal and objectives \\
\hline 6. & Careful change management \\
\hline 7. & Focus on user requirement \\
\hline 8. & Ease of system use and user acceptance \\
\hline 9. & End user satisfaction \\
\hline 10. & Adequate testing of system \\
\hline
\end{tabular}

Will discuss each critical success factor and define the relation to requirement engineering

\subsection{Good Projects Scope Management}

Project scope is a critical factor for project success. scope management represents primary activity in project management context. In the project context, the term scope can refer to two components[41]:

Product scope the features and functions that characterized product, service or result

Project scope its work performed to deliver a product, service or result with specific features and functions

From requirement and product scope definitions can conclude requirement is a component of product scope and the functional requirements are typically used in IT and software development to describe product scope, also project scope management deal with requirement collecting which help to validate and control scope[42]. the figure (1) below represent relation between requirement, scope control and scope validation [41] 


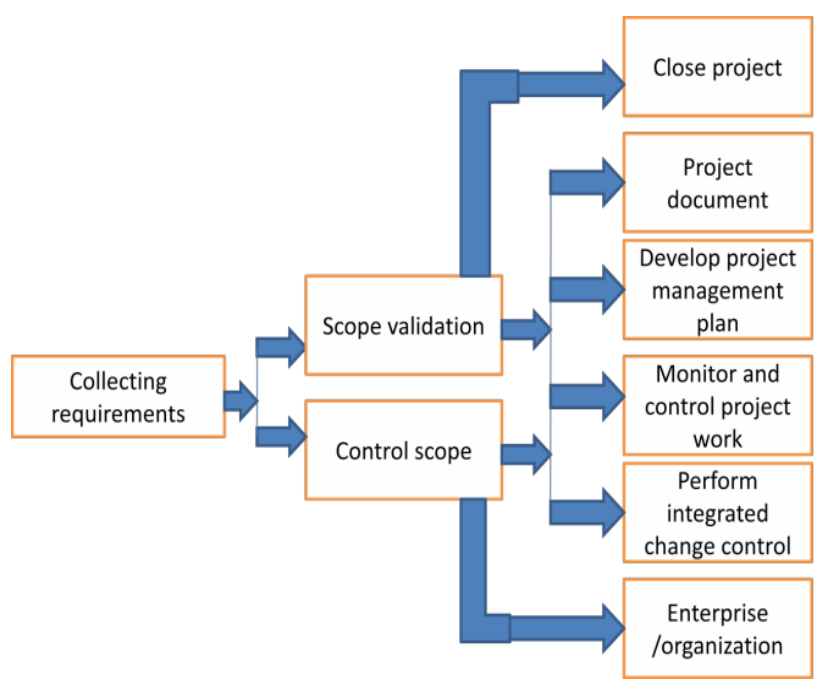

Fig 1: requirement as input for scope control and scope validation

\subsection{Regulation, Culture Change and Political Issues}

Regulation, legal text and legalization playing critical role in RE and software developing which is represent requirement and policy compliance must be recognize [43] addressing regulation as input in RE activities.

\subsection{Clear Goals and Objectives}

Software analyst must take the business environment into account to build system fulfill the organization needs. The organization need can be mapped into business goal and objectives [39].

Business goal represent number of stakeholders and their objectives/ organizational objectives and now business goal can play pivot role in capturing the details of business and system requirement. [44]

\subsection{Careful Change Management}

The implementation of ERP moving organization to new situation this change happened depend on ERP fulfill the organization needs. during implementation journey different requirement will be updated or changed without tracking and monitoring requirement change this can lead to huge problem for later stages of customization. hence RE connected strongly with change management [45]

\section{Management involvement, support and commitment}

The balance of organizational change and system customization is often decided by top management. The top management acts as the approval for any change of the requirements, also verifies and validate the product based on the organizational standards and knowledge. [46]

\subsection{End User Satisfaction}

RE life cycle concentrate on understanding business need and user requirements. Requirement definition, negotiation and change management it's one of criteria to gets user satisfaction [47]

\section{Adequate system testing}

Testing that allow to detect or prevent the defect in the system, where defect is a departure from requirement[45].

\subsection{Ease of System Use and UserAcceptance}

User acceptance it's consists of comparing of developed system to user requirements and focus on acceptance of functional and performance requirements, specified system constraints and the system external interfaces. Requirement document and defined scope is a major guidance for user acceptance. [48], [49]

\section{REQUIREMENT ENGINEERING INPUT AND CSF}

The figure [2] translate the part of CSFs mainly culture change/political issue, regulation and clear goal and objectives as REprocess inputs. [50]

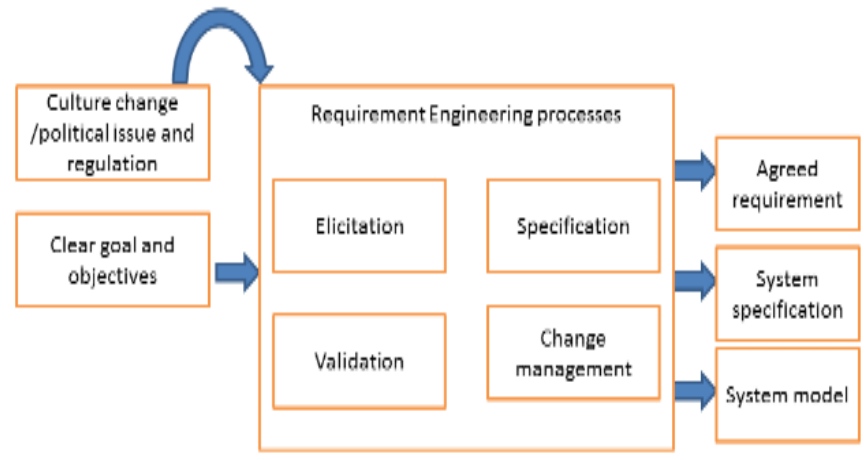

Fig 2: Critical success factors as RE processes inputs

\section{REQUIREMENTENGINEERING PROCESSES and CSF}

Table [4] defines relation of CSF at different requirement engineering process

Table 4. CSF at requirement engineering processes

\begin{tabular}{|c|c|c|c|c|}
\hline CSF & $\begin{array}{c}\text { Requirem } \\
\text { ent } \\
\text { elicitation }\end{array}$ & $\begin{array}{c}\text { Requirem } \\
\text { ent } \\
\text { analysis } \\
\text { and } \\
\text { specificati } \\
\text { on }\end{array}$ & $\begin{array}{c}\text { Requirem } \\
\text { ent } \\
\text { verificatio } \\
\text { n and } \\
\text { validation }\end{array}$ & $\begin{array}{c}\text { Requirem } \\
\text { ent } \\
\text { change } \\
\text { managem } \\
\text { ent }\end{array}$ \\
\hline $\begin{array}{c}\text { Good } \\
\text { project } \\
\text { scope } \\
\text { managem } \\
\text { ent }\end{array}$ & $\checkmark$ & $\checkmark$ & $\checkmark$ & $\checkmark$ \\
\hline $\begin{array}{c}\text { Culture } \\
\text { change / } \\
\text { political } \\
\text { issue and } \\
\text { regulation }\end{array}$ & $\checkmark$ & $\checkmark$ & $\checkmark$ & \\
\hline $\begin{array}{c}\text { Careful } \\
\text { define } \\
\text { informatio } \\
\text { n and } \\
\text { system } \\
\text { requireme } \\
\text { nts }\end{array}$ & $\checkmark$ & $\checkmark$ & $\checkmark$ & \\
\hline $\begin{array}{c}\text { Clear goal } \\
\text { and } \\
\text { objectives }\end{array}$ & $\checkmark$ & & $\checkmark$ & \\
\hline $\begin{array}{c}\text { Careful } \\
\text { change } \\
\text { managem }\end{array}$ & & & & \\
\hline
\end{tabular}




\begin{tabular}{|c|c|c|c|c|}
\hline ent & & & & \\
\hline $\begin{array}{c}\text { Managem } \\
\text { ent } \\
\text { involveme } \\
\text { nt. support } \\
\text { and } \\
\text { commitme } \\
\text { nt }\end{array}$ & $\checkmark$ & & $\checkmark$ & $\checkmark$ \\
\hline $\begin{array}{c}\text { Focus on } \\
\text { user } \\
\text { requireme } \\
\text { nt }\end{array}$ & $\checkmark$ & $\checkmark$ & $\checkmark$ & $\checkmark$ \\
\hline $\begin{array}{c}\text { End user } \\
\text { satisfactio } \\
\mathrm{n}\end{array}$ & & $\checkmark$ & $\checkmark$ & \\
\hline $\begin{array}{c}\text { Adequate } \\
\text { testing of } \\
\text { system }\end{array}$ & & & $\checkmark$ & \\
\hline $\begin{array}{c}\text { Ease of } \\
\text { system } \\
\text { use and } \\
\text { user } \\
\text { acceptanc } \\
\mathrm{e}\end{array}$ & & & $\checkmark$ & \\
\hline
\end{tabular}

\section{CONCLUSION}

Successfully implementing ERP system has many benefits for organizations. However, on other hand, failing this project would have several negative implications not only on the business but also on the ERP vendor. Therefore, considering all the factors that might affect the success of this project is considered as a priority for all parties involved in it. Therefore, many authors of the scientific journal papers have highlighted the importance of considering the positive and negative factors in the implementation project of the Enterprise Resource Planning (ERP) system. (ERP) system. This paper has reviewed the articles related to influencing factors that need to be wellthought-out throughout all stages of the ERP system implementation life cycle and focus to define the relation of these factors with requirements engineering activity.

\section{REFERENCES}

[1] C. V Bullen and J. F. Rockart, "A primer on critical success factors," 1981.

[2] J. Ram, D. Corkindale, and M.-L. Wu, "Implementation critical success factors (CSFs) for ERP: Do they contribute to implementation success and post-implementation performance?," Int. J. Prod. Econ., vol. 144, no. 1, pp. 157174, 2013.

[3] M. M. Ahmad and R. P. Cuenca, "Critical success factors for ERP implementation in SMEs," Robot. Comput. Integr. Manuf., vol. 29, no. 3, pp. 104-111, 2013.

[4] L. Shaul and D. Tauber, "Critical success factors in enterprise resource planning systems: Review of the last decade," ACM Comput. Surv., vol. 45, no. 4, p. 55, 2013.

[5] A. Amid, M. Moalagh, and A. Z. Ravasan, "Identification and classification of ERP critical failure factors in Iranian industries," Inf. Syst., vol. 37, no. 3, pp. 227-237, 2012.
[6] M. R. Osman, R. M. Yusuff, S. H. Tang, and S. M. Jafari, "ERP systems implementation in Malaysia: the importance of critical success factors," 2006.

[7] C. Doom, K. Milis, S. Poelmans, and E. Bloemen, "Critical success factors for ERP implementations in Belgian SMEs," J. Enterp. Inf. Manag., vol. 23, no. 3, pp. 378-406, 2010 .

[8] A. Tarhini, H. Ammar, T. Tarhini, and others, "Analysis of the critical success factors for enterprise resource planning implementation from stakeholders perspective: A systematic review,” Int. Bus. Res., vol. 8, no. 4, p. 25, 2015.

[9] M. Kauppinen, M. Vartiainen, J. Kontio, S. Kujala, and R. Sulonen, "Implementing requirements engineering processes throughout organizations: success factors and challenges," Inf. Softw. Technol., vol. 46, no. 14, pp. 937 953, 2004

[10] M. Niazi and S. Shastry, "Critical success factors for the improvement of requirements engineering process," in Verified OK, 2003.

[11] T. M. Somers and K. G. Nelson, "A taxonomy of players and activities across the ERP project life cycle," Inf. Manag., vol. 41, no. 3, pp. 257-278, 2004.

[12] T. M. Somers and K. Nelson, "The impact of critical success factors across the stages of enterprise resource planning implementations," in System Sciences, 2001 Proceedings of the 34th Annual Hawaii International Conference on, 2001, p. 10--pp.

[13] V. B. Gargeya and C. Brady, "Success and failure factors of adopting SAP in ERP system implementation," Bus. Process Manag. J., vol. 11, no. 5, pp. 501-516, 2005.

[14] T. H. Davenport, "Putting the enterprise into the enterprise system,” Harv. Bus. Rev., vol. 76, no. 4, 1998.

[15] M. Sumner, "Critical success factors in enterprise wide information management systems projects," in Proceedings of the 1999 ACM SIGCPR conference on Computer personnel research, 1999, pp. 297-303.

[16] S. Buckhout, E. Frey, and J. Nemec, "Making ERP succeed: turning fear into promise," Strateg. Bus., pp. 60 73, 1999 .

[17] P. Bingi, M. K. Sharma, and J. K. Godla, "Critical issues affecting an ERP implementation," IS Manag., vol. 16, no. 3, pp. 7-14, 1999.

[18] O. Françoise, M. Bourgault, and R. Pellerin, "ERP implementation through critical success factors' management," Bus. Process Manag. J., vol. 15, no. 3, pp. 371-394, 2009.

[19] S. Finney and M. Corbett, "ERP implementation: a compilation and analysis of critical success factors," Bus. Process Manag. J., vol. 13, no. 3, pp. 329-347, 2007.

[20] F. F.-H. Nah, K. M. Zuckweiler, and J. Lee-Shang Lau, "ERP implementation: chief information officers' perceptions of critical success factors," Int. J. Hum. Comput. Interact., vol. 16, no. 1, pp. 5-22, 2003.

[21] U. Remus, "Critical success factors for implementing enterprise portals: A comparison with ERP implementations," Bus. Process Manag. J., vol. 13, no. 4, pp. 538-552, 2007. 
[22] F. Fui-Hoon Nah, J. Lee-Shang Lau, and J. Kuang, "Critical factors for successful implementation of enterprise systems," Bus. Process Manag. J., vol. 7, no. 3, pp. 285296, 2001.

[23] H. Seng Woo, "Critical success factors for implementing ERP: the case of a Chinese electronics manufacturer," J. Manuf. Technol. Manag., vol. 18, no. 4, pp. 431-442, 2007.

[24] J. Yingjie, "Critical success factors in ERP implementation in Finland," Swedish Sch. Econ. Bus. Adm., vol. 71, 2005.

[25] E. J. Umble, R. R. Haft, and M. M. Umble, "Enterprise resource planning: Implementation procedures and critical success factors," Eur. J. Oper. Res., vol. 146, no. 2, pp. 241-257, 2003.

[26] J. G. Rosario, "On the leading edge: critical success factors in ERP implementation projects," Bus. World, vol. 17, no. May, pp. 15-29, 2000

[27] C. P. Holland and B. Light, "A critical success factors model for ERP implementation," IEEE Softw., no. 3, pp. 30-36, 1999.

[28] T. R. Bhatti and others, "Critical success factors for the implementation of enterprise resource planning (ERP): empirical validation," in the second international conference on innovation in information technology, 2005, vol. 110.

[29] D. Aloini, R. Dulmin, and V. Mininno, "Risk management in ERP project introduction: Review of the literature," Inf Manag., vol. 44, no. 6, pp. 547-567, 2007.

[30] C. C. Chen, C. C. H. Law, and S. C. Yang, "Managing ERP implementation failure: a project management perspective," IEEE Trans. Eng. Manag., vol. 56, no. 1, pp. 157-170, 2009.

[31] S. Maguire, U. Ojiako, and A. Said, "ERP implementation in Omantel: a case study,” Ind. Manag. Data Syst., vol. 110, no. 1, pp. 78-92, 2010.

[32] E. W. T. Ngai, C. C. H. Law, and F. K. T. Wat, "Examining the critical success factors in the adoption of enterprise resource planning," Comput. Ind., vol. 59, no. 6, pp. 548564, 2008.

[33] L. F. Motiwalla and J. Thompson, Enterprise systems for management. Pearson Boston, MA, 2012.

[34] P. Mandal and A. Gunasekaran, "Issues in implementing ERP: A case study,” Eur. J. Oper. Res., vol. 146, no. 2, pp. 274-283, 2003.

[35] J. E. Scott and I. Vessey, "Implementing enterprise resource planning systems: the role of learning from failure," Inf. Syst. Front., vol. 2, no. 2, pp. 213-232, 2000.

[36] S. Saini, S. Nigam, and S. C. Misra, "Identifying success factors for implementation of ERP at Indian SMEs: a comparative study with Indian large organizations and the global trend," J. Model. Manag., vol. 8, no. 1, pp. 103-122, 2013.
[37] S.-M. Huang, I.-C. Chang, S.-H. Li, and M.-T. Lin, "Assessing risk in ERP projects: identify and prioritize the factors," Ind. Manag. data Syst., vol. 104, no. 8, pp. 681688, 2004.

[38] S. Dezdar and S. Ainin, "The influence of organizational factors on successful ERP implementation," Manag. Decis. vol. 49, no. 6, pp. 911-926, 2011.

[39] M. Tarafdar and R. K. Roy, "Analyzing the adoption of enterprise resource planning systems in Indian organizations: a process framework," J. Glob. Inf. Technol. Manag., vol. 6, no. 1, pp. 21-51, 2003.

[40] A. M. Aladwani, "Change management strategies for successful ERP implementation," Bus. Process Manag. J., vol. 7, no. 3, pp. 266-275, 2001.

[41] K. H. Rose, "A Guide to the Project Management Body of Knowledge (PMBOK®Guide) Fifth Edition," Proj. Manag. J., vol. 44, no. 3, pp. e1--e1, 2013.

[42] J. Moustafaev, Project scope management: A practical guide to requirements for engineering, product, construction, IT and enterprise projects. Auerbach Publications, 2014.

[43] P. N. Otto and A. I. Antón, "Addressing legal requirements in requirements engineering," in Requirements Engineering Conference, 2007. RE'07. 15th IEEE International, 2007, pp. 5-14.

[44] A. Ullah and R. Lai, "Modeling business goal for business/it alignment using requirements engineering," J. Comput. Inf. Syst., vol. 51, no. 3, pp. 21-28, 2011.

[45] J. Dick, E. Hull, and K. Jackson, Requirements engineering. Springer, 2017.

[46] A. Haron and S. Sahibuddin, "The roles of an actor in requirement engineering (RE) process," in Computer Science and Information Technology (ICCSIT), 2010 3rd IEEE International Conference on, 2010, vol. 1, pp. 436440.

[47] J. Elliott and P. Raynor-Smith, "Achieving customer satisfaction through requirements understanding," in European Workshop on Software Process Technology, 2000, pp. 203-219.

[48] P. Hsia, D. Kung, and C. Sell, "Software requirements and acceptance testing," Ann. Softw. Eng., vol. 3, no. 1, pp. 291-317, 1997.

[49] J. Coughlan and R. D. Macredie, "Effective communication in requirements elicitation: a comparison of methodologies," Requir. Eng., vol. 7, no. 2, pp. 47-60, 2002

[50] S. Jan and M. N. Majeed, "Role of Requirement Management as a CMMI Process Area in Requirement Engineering,” Int. J. Comput. Appl., vol. 51, no. 19, 2012. 